\title{
IDENTITAS ARSITEKTUR: PENCARIAN HAKIKAT RUANG MELALUI PERMUKIMAN KUMUH
}

\section{Fatimatuz Zahroh}

Mahasiswa Program Studi Arsitektur

Universitas Pembangunan Nasional

"Veteran" Jawa Timur

ftm.zahroh@gmail.com

\section{Lutvi Arnila Meiliyandari}

Mahasiswa Program Studi Arsitektur

Universitas Pembangunan Nasional

"Veteran" Jawa Timur

lutviarnila1@gmail.com

\section{lis Septianingrum}

Mahasiswa Program Studi Arsitektur Universitas Pembangunan Nasional

"Veteran" Jawa Timur

septhianingrum11@gmail.com

\begin{abstract}
ABSTRAK
Pemaknaan arsitektur tidak pernah memiliki pakem dari para praktisi maupun teoritikus. Pencarian identitas arsitektur terus dikaji dan berlanjut hingga menghasilkan ragam definisi yang tumpang-tindih dalam aktualisasinya, sebut saja teori Vitruvius dan Wastu Widya. Arsitektur kemudian disempitkan lagi oleh pandangan publik yang hanya sebatas bangunan indah. Paradigma ini kemudian melahirkan pemikiran bahwa bangunan dengan tampilan yang indah adalah arsitektur, sebaliknya bangunan yang kotor dan kumuh adalah bukan arsitektur. Padahal lebih luas dari itu arsitektur juga merupakan alat penyelesaian masalah sosial yang berusaha menghilangkan disparitas sosial yang terjadi. Disparitas ini berwujud dalam bentuk hunian kumuh atau slum yang dianggap sebagai sumber permasalahan. Dengan mengumpulkan data dari hasil penelitian maupun isu terkini tentang bagaimana melakukan pendekatan arsitektur pada kawasan slum, tanpa harus menghapuskan keberadaannya, tetapi dengan meningkatkan derajatnya seperti yang dilakukan oleh Romo Mangun di Kali Codhe, penelitian menunjukkan bahwa slum adalah salah satu solusi dalam mendesain perumahan sosial skala massal yang bisa meningkatkan taraf hidup sekaligus sosial penghuni di dalamnya.
\end{abstract}

KATA KUNCI:, perumahan sosial, slum architecture.

\section{PENDAHULUAN}

Marginalisasi pada masyarakat memang tidak dapat terhindarkan keberadaannya. Diberitakan pada portal daring Kompas mengenai meningkatnya pertumbuhan ekonomi Indonesia menjadi peringkat ke-3 dibawah China dan India di antara negaranegara G-20 yang diiringi dengan meningkatnya ketimpangan ekonomi (Tjoe, Y., 2018). Hal ini tercermin dalam Indeks Gini (lihat gambar 1), yakni indeks untuk mengukur ketimpangan ekonomi dalam sebuah negara dari 0 (kesetaraan sempurna) sampai 100 (ketidaksetaraan sempurna).

Ketimpangan ekonomi ini juga ikut meningkatkan urbanisasi masyarakat desa ke kotakota besar di Indonesia untuk mengadu nasib. Menurut catatan World Bank (2013) laju urbanisasi di Indonesia sekitar 4,1 persen per tahun tumbuh lebih cepat daripada negara Asia lainnya. World Bank memprediksi pada tahun 2025 sebanyak 68 persen populasi Indonesia akan berpusat di kota.

Tidak sedikit yang mendirikan permukiman informal dikarenakan rendahnya ekonomi untuk membeli, menyewa ataupun mengontrak rumah. Dilihat dari sisi perencanaan kota, hal ini memang menjadi suatu permasalahan karena merusak tata kota yang telah dirancang, tetapi dilihat dari segi sosial, hal ini adalah hal yang normal sebagai bentuk pertahanan diri dan sebagai bukti bahwa manusia adalah makhluk ekonomi yang tergiur dengan kemajuan dan kemapanan di kota besar. Berharap dengan menjadi bagian dari penghuni kota besar, maka akan mampu memenuhi kebutuhan ekonominya sehari-hari.

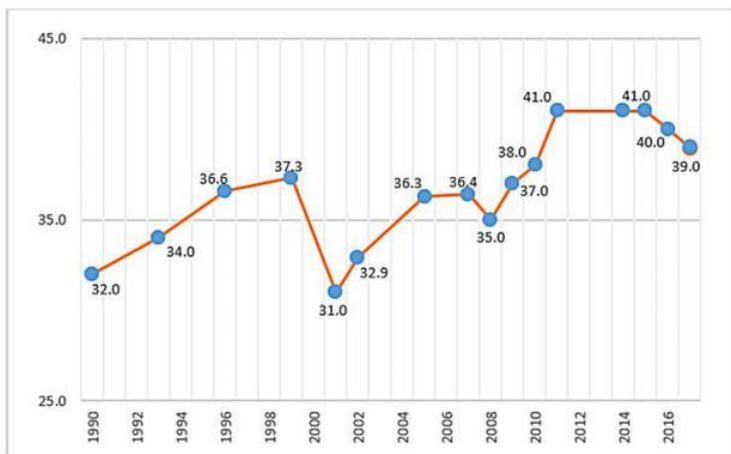

Gambar 1. Indeks Gini Indonesia, 1990 - 2017 (Sumber: Tjoe, Y, 2018)

Permukiman informal merupakan efek samping dari pertumbuhan penduduk yang tidak seimbang dengan pengadaan fasilitas sarana dan prasarana yang merata, memadai dan mencukupi. Angka 
urbanisasi tinggi, sedangkan daya dukung lingkungan di kota sudah tidak mampu mengatasi beban aktvitas yang ada di dalamnya. Meningkatnya jumlah manusia secara signifikan tanpa disertai dengan pemenuhan sarana mengakibatkan terjadinya degradasi lingkungan yang memicu munculnya permukiman kumuh atau biasanya disebut dengan slum.

Menurut Peraturan Pemerintah No. 14 Tahun 2016 tentang Perumahan dan Permukiman, permukiman kumuh adalah permukiman yang tidak layak huni, antara lain karena berada di atas lahan yang tidak sesuai dengan peruntukan atau tata ruang, kepadatan bangunan yang sangat tinggi dalam luasan yang sangat terbatas, rawan penyakit sosial dan penyakit lingkungan, kualitas umum bangunan rendah, tidak terlayani prasarana lingkungan yang memadai, membahayakan keberlangsungan kehidupan penghuninya.

Permukiman kumuh dapat diartikan sebagai suatu lingkungan permukiman yang telah mengalami penurunan kualitas atau memburuk secara fisik, sosial ekonomi maupun sosial budaya, yang tidak mungkin dicapainya kehidupan yang layak bagi penghuninya. Dapat pula dikatakan bahwa para penghuni permukiman kumuh benar-benar dalam lingkungan yang sangat membahayakan kehidupannya.

Untuk menentukan apakah suatu kawasan merupakan permukiman kumuh dibutuhkan parameter penilaian yang didasarkan pada beberapa komponen, yaitu komponen fisik; komponen sanitasi lingkungan; komponen sosial kependudukan; dan komponen ekonomi.

1. Komponen Fisik

a. Penggunaan Lahan

b. Keadaan Permukiman

c. Kondisi Fisik Lingkungan

2. Komponen Sanitasi Lingkungan

a. Kecukupan sumber air bersih

b. Pemanfaatan MCK oleh warga

c. Pembuangan air limbah

d. Kondisi saluran air

e. Penumpukan dan upaya pengelolaan sampah

f. Frekuensi banjir

g. Kondisi jalan lingkungan

h. Kondisi penerangan

3. Komponen sosial kependudukan

a. Jumlah penduduk

b. Komposisi penduduk

c. Kepadatan penduduk

d. Pendidikan penduduk

e. Kesehatan penduduk

4. Komponen sosial budaya

a. Kebiasaan penduduk

b. Adat istiadat
5. Komponen Ekonomi

a. Tingkat pendapatan

b. Aktivitas ekonomi atau mata pencaharian penduduk

c. Sarana atau fasilitas penunjang kegiatan ekonomi

Dalam praktik penyelesaian masalah tersebut, pemerintah seiringkali mengambil solusi yang belum menyentuh persoalan dasar yaitu kesejahteraan masyarakat. Salah satu program untuk menyelesaikan masalah permukiman kumuh adalah progam Kotaku (Kota Tanpa Kumuh) yang digagas untuk mengatasi keberadaan permukiman kumuh di kota-kota besar di Indonesia. Yu Sing, Arsitek dari Studio Akanoma dalam berita daring Kompas menyatakan bahwa program tersebut belum menyasar aspek kesejahteraan masyarakat. Kriteria-kriteria yang diperbaiki dalam permukiman kumuh hanya seputar kosmetik seolah-olah agar tidak berantakan.

Hal ini menjadi salah satu poin yang paling mencolok dari ketimpangan ekonomi di Indonesia dengan membangun stigma buruk terhadap permukiman informal. Stigma ini didukung oleh paradigma berarsitektur di Indonesia yang kurang memiliki fokus pada aspek sosial. Berbeda dengan budaya arsitektur nusantara di Indonesia yang sudah terintegrasi dengan kehidupan sosial Indonesia yang multikultural dan jamak, budaya berarsitektur di Eropa yang berkembang dari teori Vitruvius berbasis pada logika dan terpisah dari budaya masyarakat. Paradigma demikian menimbulkan ketimpangan yang lain dalam budaya berarsitektur di Indonesia. Melihat hal ini Romo Mangun merumuskan suatu jalan tengah dimana budaya berarsitektur di Indonesia bisa lebih mengakar pada budaya asalnya.

Dari sisi arsitektur, tulisan ini mengkritik sikap gegabah pemerintah terhadap permukiman informal yang ada di kota-kota besar, juga kepada pihak arsitek yang berpraktik secara individualistis dan kurang memberikan perhatian terhadap aspek sosial dalam perancangan arsitektur. Dengan menjadikan kinerja Romo Mangun sebagai preseden untuk merevitalisasi permukiman kumuh Kali Codhe, perbaikan permukiman informal seharusnya tidak hanya menyasar aspek fisik arsitektur, tetapi juga mentalitas masyarakat. Sehingga tidak hanya memperbaiki lingkungan, tetapi juga kesejahteraan masyarakat.

\section{BAGIAN INTI}

Paradigma dalam arsitektur dapat berganti yang bisa saja berbeda antarnegara dikarenakan perbedaan sosial, budaya, iklim, ekonomi, edukasi, teknologi dan perbedaan lainnya. Dalam hal ini arsitektur memiliki dimensi humaniora, yakni arsitektur dari dan untuk manusia. 
Menurut Anthonius N. Tandal (2011) antara arsitektur dan perilaku terdapat hubungan yang erat. Hal ini dapat dilihat dari aspek-aspek pembentuk perilaku manusia akibat lingkungan atau bentuk arsitektur dan sebaliknya. Dengan kata lain perilaku manusia dapat diarahkan ke arah yang lebih baik jika nilai-nilai positif dari lingkungan atau bentuk arsitektur dapat membentuk kepribadian serta perilaku yang memiliki nilai positif. Dengan kata lain ketika merancang, seorang arsitek diandaikan membuat asumsi-asumsi tentang kebutuhan manusia, memperkirakan bagaimana manusia berperilaku, bergerak dalam lingkungannya, lalu memutuskan bagaimana bangunan tersebut dapat menjadi lingkungan yang sehat bagi manusia pemakainya.

Arsitek bekerja untuk memenuhi kebutuhan manusia juga untuk meningkatkan potensi yang dimilikinya. Potensi dalam hal ini tidak hanya terbatas pada ekonomi, salah satu potensi selainnya yang berbasis lingkungan adalah potensi lingkungan desa. Menurut Drs. Abdurrokhman, M.Pd. (2014) potensi desa dapat dibedakan menjadi dua. Pertama adalah potensi fisik berupa tanah, air, iklim, lingkungan geografis, binatang ternak, dan sumber daya manusia. Kedua adalah potensi non fisik berupa masyarakat dengan corak dan interaksinya, lembagalembaga sosial, lembaga pendidikan, organisasi sosial desa, serta aparatur dan pamong desa.

Dalam KBBI, desa bisa diartikan sebagai kelompok rumah di luar kota yang merupakan kesatuan. Oleh karena itu daerah di pinggir kota-kota besar yang jauh dari pusat kota dan berada di sepanjang perimeter terluar kota dapat disebut desa. Sejauh ini paradigma desa seakan-akan memberikan harapan akan ketersediaan ekonomi yang cukup dimana pertanian dan peternakan masih dapat dilakukan. Dengan tidak meratanya ekonomi di desa dan kapitalisasi di kota membuat daerah terluar kota kurang mendapatkan perhatian oleh pemerintah, sehingga mendorong terjadinya laju urbanisasi yang tinggi di Indonesia.

Urbanisasi memiliki imbas terhadap permasalahan permukiman kumuh yang tersebar di kota-kota besar. Namun solusi yang ditawarkan oleh pemerintah seringkali hanya bersifat instan dan cenderung gegabah, sebut saja penggusuran. Solusi seperti ini tentu tidak menyelesaikan akar masalah permukiman kumuh.

Menurut Lembaga Bantuan Hukum Jakarta dalam Laporan Penggusuran Paksa di Wilayah DKI Jakarta, pada tahun 2015 ditemukan terjadi sebanyak 113 kali dan ditahun 2016 terjadi sebanyak 193 kali penggusuran dengan porsi terbesarnya dilakukan secara paksa oleh pemerintah tanpa adanya komunikasi dengan masyarakat yang akan digusur.
Pada gambar di bawah menunjukkan grafik persentase prosedur penggusuran yang dilakukan oleh pemerintah.

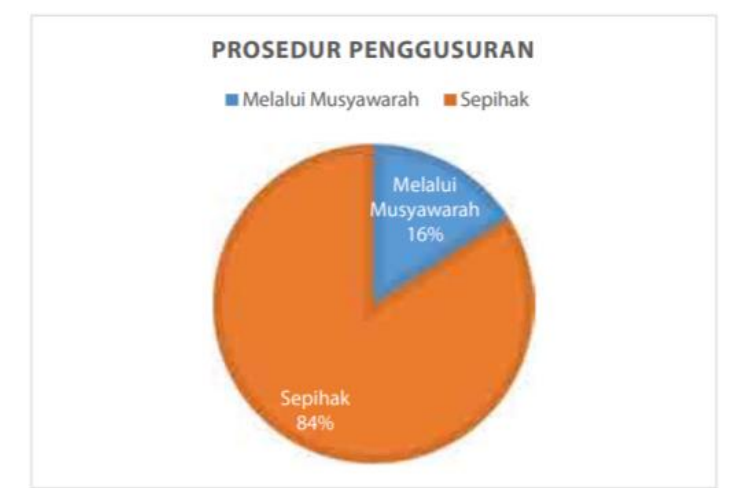

Gambar 2. Persentase prosedur penggusuran Tahun 2015 oleh pemerintah (Sumber: L. B. H., JAWAB, P., \& SAMPUL, D., 2015

\section{Prosedur Penggusuran Hunian}
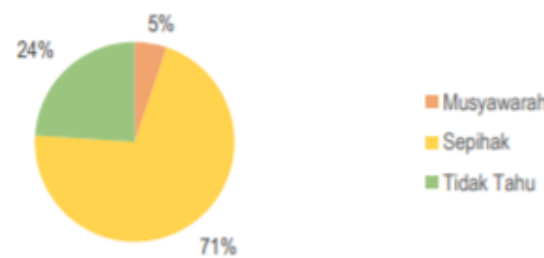

Gambar 3. Persentase prosedur penggusuran tahun 2016 oleh pemerintah

(Sumber : L. B. H., JAWAB, P., PENYUSUN, T., \& SAMPUL, D., 2017)

Pemaksaan ini walaupun ditujukan untuk perbaikan infrastruktur dan lingkungan dalam skala yang lebih besar, tetapi perlu diingat perbuatan yang sepihak ini tidak dibenarkan menurut Committee on Economic, Social and Cultural Rights, General Comment 7, Forced evictions, and the right to adequate housing (Sixteenth session, 1997), U.N. Doc. E/1998/22, annex IV at 113 (1997) pasal 2 yang menyatakan, The International community has long recognised that the issue of forced evictions is a serious one. In 1976 the Vancouver Declaration on Human Settlements noted that "major clearance operations should take place only when conservation and rehabilitation are not feasible and relocation measures are made".

Pernyataan di atas menjelaskan bahwa dalam melakukan penggusuran, pemerintah harus memiliki rencana lanjutan untuk memberikan tempat baru bagi korban penggusuran, contohnya dengan membangun rumah susun yang dirancang dengan pertimbangan berbagai aspek, meliputi sosial, budaya, ekonomi, dan lainnya, sehingga sustainability dapat tercipta dan penghuninya pun dapat berperan 
aktif dalam menunjang keberlangsungan hidup maupun keberadaan rumah susun tersebut.

Masih berhubungan dengan pasal di atas, in the 1988 Global Strategy for Shelter to the Year 2000, the General Assembly recognized the "fundamental obligation (of Governments) to protect and improve houses and neighbourhoods, rather than damage or destroy them". Agenda 21 stated that "people should be protected by law against unfair eviction from their homes or land".

Tindakan pemerintah yang sepihak itu tidak akan menyelesaikan akar masalah urbanisasi yang pasti akan terus terjadi. Tindakan pemerintah hanya merupakan solusi jangka pendek yang pada akhirnya akan merugikan pemerintah. Tindakan yang sebenarnya bisa dicegah atau dikurangi dampaknya jika saja arsitek mau bertindak dan memberikan solusi untuk masyarakat.

Salah satu arsitek ternama yang terkenal dengan kontribusinya pada masyarakat secara menyeluruh adalah Romo Mangun, seorang arsitek dan juga pastor Katolik yang memilih untuk membaktikan hidupnya dengan berarsitektur untuk rakyat yang tertindas oleh birokrasi pemerintah. Dalam salah satu kesempatan, Romo Mangun mengkritik para frater dalam seminari, "Saya prihatin tentang kalian. Karena calon gembala umat tidak pernah dilatih untuk ajurajer (melebur) dengan masyarakat. Terlalu banyak dijejali filsafat dan teologi," (Hadiatmojo, 2013: 2).

Romo Mangun menjadi advokat dalam kasus Kali Codhe, Gunungkidul dan Kedung Ombo. Kali Codhe menghasilkan luaran desain yang terkenal hingga dianugerahi Aga Khan Award pada tahun 1992 dan bersumbangsih dalam mengembangkan kualitas hidup maupun lingkungan masyarakat bantaran sungai yang sebelumnya terancam digusur.

Romo Mangun yang hingga saat ini masih dieluelukan namanya sebagai arsiteknya rakyat kecil menjadi idola sekaligus menjadi bias bagi generasi arsitek-arsitek selanjutnya, terutama di era infomasi yang semakin cepat ini. Di mana visual semakin diperkaya tapi pembelajaran atas "rasa" dan kesadaran dalam bersosial semakin berkurang (Prasetyo, 2017: 9). Perancang saling berlomba untuk menciptakan desain yang menakjubkan, breathtaking, dan berbagai istilah lainnya yang merujuk pada estetika semata. Banyak dari desain yang dihasilkan malah menjadi alien di daerah terbangunannya. Sisi "menakjubkannya" justru membuatnya terlihat berbeda dan keluar dari keadaan sosial-budaya masyarakat sekitar. Pada perspektif lain hal ini dapat mengangkat kreativitas para pengkajinya, tetapi bagi masyarakat sekitar tidak merasakan manfaat secara langsung dari desain yang terbangun baik dari segi sosial maupun ekonomi. Dalam jurnal Raluca Livia Niculae (2016) mengutip tulisan Witold Rybczynski, "Architecture is a social art, rather than a personal one, a reflection of a society and its values rather than a medium of individual expression. So it's a problem when the prevailing trend is one of franchises, particularly those of the globe-trotters: Renzo, Rem, Zaha, and Frank."

Desain tidak semata-mata dibuat untuk memenuhi kebutuhan estetika, tetapi juga sebagai alat sosial. Romo Mangun sadar betul akan hal ini dan mengemukakannya pada sebuah teori arsitektur yang disebut Dwilogi Mangunwijaya, di mana substansi yang membentuk arsitektur adalah Guna dan Citra. Dalam pandangannya ketika berarsitektur, Romo Mangunwijaya menyatukan keduanya -- seni dan teknologi-- dengan analogi bersatunya jasmani dan rohani; "Jadi bukan dualisme: jasmani dan rohani, melainkan kesatuan tunggal hakiki; jasmani-rohani, itulah manusia (Mangunwijaya, 1995: 4). Y.B Mangunwijaya juga memberikan "jiwa" terhadap rumah dan menganggap bahwa rumah adalah manusia. Sebagai jiwa, tentu rumah mencerminkan sesuatu, mencerminkan pemiliknya dan mencerminkan tempat di mana rumah tersebut hidup.

"Guna" oleh Yusuf Bilyarta Mangunwijaya didefinisikannya sebagai keuntungan; pemanfaatan yang diperoleh; pelayanan yang kita dapatkan darinya. Guna dalam arti kata aslinya tidak hanya berarti bermanfaat, untung material belaka, tetapi lebih dari itu punya "daya" yang menyebabkan kita bisa hidup lebih meningkat. Sedang elemen "Citra" dipaparkan oleh Romo Mangunwijaya sebagai suatu gambaran (image), suatu kesan penghayatan yang menangkap arti bagi seseorang. Citra tidak jauh dari guna, tetapi lebih bertingkat spiritual, lebih menyangkut derajat dan martabat manusia yang menghuni bangunannya. Lebih lanjut Romo Mangun menulis bahwa "Citra" menunjuk pada tingkat kebudayaan, sedangkan "Guna" lebih menuding pada segi ketrampilan atau kemampuan. Citra adalah "lambang yang membahasakan" segala yang manusiawi, indah dan agung dari dia yang membangunnya.

Teori yang masih digunakan hingga saat ini dalam praktik maupun pendidikan arsitektur adalan teori dari Marcus Vitruvius; seorang ahli bangunan di zaman Romawi Kuno, yang dikenal dengan sebutan Trilogi Vitruvius, sebagaimana disebutkan dalam buku The Ten Books on Architecture (Buku I, Chap.III, point 2) "All these must be built withdue reference to durability (fimitas), convience (utilitas), and beauty (venustas). Durability will be assured when foundations are carried down to the solid ground and materials wisely and liberally selected; convenience, when the arragement of the apartement is faultless and presents no hindrance to use, and when each 
class of building is assigned to its suitable and appropriate exposure; and beauty, when the work apprence of the work is pleasing and good taste, and them its members are in due proportion according to correct principles of symmetry" (Brown, F. E, 1963).

Teori Vitrivius tidak relevan dengan arsitektur di daerah Timur. Menurut Istanto, H. Freddy (1999), isi teori tersebut menyebutkan hal umum dan hanya secara fisik bahwa bangunan harus memenuhi persyaratan firmitas, utilitas, dan venustas. Ketiganya merupakan logika dasar bangunan, seputar bagaimana bangunan akan terlihat dan seputar bagaimana seharusnya bangunan tersebut akan berdiri. Dalam tulisan Burhany (2010) menjelaskan bagaimana arsitektur Barat sangat material dan arsitektur Timur sangat spiritual dan dengan lebih tersorotnya teori Vitruvius sebagai teori dasar berarsitektur tentu saja menyempitkan arsitektur yang berhubungan dengan nilai-nilai dan konsep alam, Tuhan, dan manusia yang menjadi dasar dalam berkehidupan di Nusantara; dengan kita menghormati Tuhan sebagai pencipta alam semesta, maka hakikatnya kita juga menghormati, menjaga dan melestarikan ciptaannya di Bumi, meliputi alam dan manusia.

Dalam teori Vitruvius tidak sedikitpun menjelaskan tentang kebiasaan manusia yang berpengaruh terhadap arsitektur, pun tidak menjelaskan bagaimana bangunan beritegrasi dengan alam, atau bagaimana kepercayaan terhadap Tuhan mempengaruhi arsitektur. Teori ini seperti membuat paradigma arsitektur hanya sebuah 'wadah' manusia. Sesungguhnya arsitektur bukanlah sekumpulan bahan bangunan yang didirikan di atas sebidang tanah saja, tetapi sebuah arsitektur membawa sejumlah isu-isu kompleks seperti aspek-aspek sosial, budaya dan teknologi.

\section{PENUTUP}

Kesimpulan dari kajian ini adalah teori Vitruvius kurang relevan dengan kondisi sosial-budaya di Indonesia. Teori ini sebatas mencakup logika dan fisika bangunan yang paling dasar. Sedangkan dalam arsitektur di Indonesia, arsitektur mengakar pada budaya sebagai aspek yang tidak tercakup dalam teori Vitruvius. Arsitektur di Indonesia adalah anak dari kondisi sosial-budaya masyarakat, sehingga jika teori Vitruvius diaplikasikan di Indonesia maka yang tercipta adalah bangunan yang tidak mencerminkan karakter budaya Indonesia dan menciptakan paradigma bahwa slum adalah suatu permasalahan dan bukan bagian dari kota sehingga sah-sah saja untuk digusur. Jika dilihat dari sudut pandang teori Romo Mangun, maka slum sudah memenuhi guna dan citra. Dengan pendalaman dari segi sosial, slum masihlah bagian dari ruang kota yang membutuhkan pemberdayaan. Tidak dapat dipungkiri sumbangsih pemerintah maupun para arsitek dan akademisi perancangan kota akan dapat meningkatkan kualitas taraf hidup masyarakat yang bermukim di area slum dan menghilangkan stigma negatif terkait permukiman kumuh.

\section{DAFTAR PUSTAKA}

Abdurrokhman, D., \& Pd, M., 2014, Pengembangan Potensi Desa. Widyaiswara pada Kantor Diklat Kabupaten Banyumas.

Brown, F. E., 1963, Vitruvius and the liberal art of architecture. The Bucknell Review, 11(4), 99.

Burhany, N. R., 2010, Dialog Kritis Trilogi Vitruvius Vs. Dwilogi Mangunwijaya. MEKTEK, 12(1).

Hadiatmojo, Y., 2013, Kotak Hitam Sang Burung Manyar. Galangpress.

Istanto, F. H., 1999, Arsitektur "Guna dan Citra" Sang Romo Mangun. Dimensi Teknik Arsitektur, 27(2).

LBH Jakarta, 2017, Seperti Puing: Laporan Penggusuran Paksa di Wilayah DKI Jakarta Tahun 2016, www. bantuanhukum. Or, id/web/sepertipuing-laporan-penggusuran-paksa-di-wilayahdki-jakarta-tahun-2016

Niculae, R. L., 2016, Between responsibility and starchitecture. Review of Applied SocioEconomic Research, Volume 11, Issue 1, pp.67.

Sunaryo, R., 2007, Mengikuti Langkah Pikir Romo Mangun: Sebuah Tinjauan Mengenai Metode Perancangan Arsitektur Yusuf Bilyarta Mangunwijaya, http://dimensi.petra.ac.id/index.php/ars/article /view/16624/16616, diakses 14 January 2020.

Tandal, Anthonius N., \& Egam, P. P., 2011, Arsitektur berwawasan perilaku (behaviorisme). Media Matrasain, 8(1).

Tjoe, Yenny., 2018, Seberapa Parah Ketimpangan Ekonomi di Indonesia?, www.kompas.com, https://ekonomi.kompas.com/read/2018/08/31 /100200826/seberapa-parah-ketimpanganekonomi-di-indonesia. 